\title{
Heavy Metal Contamination of Soil and Health Hazards Among the Residents of Tannery Industrial Area
}

\author{
*ANMM Uddin ${ }^{1}$, SA Ahmed ${ }^{2}$
}

\begin{abstract}
Background: Heavy metals like chromium compounds can be carcinogenic usually used in the tanning process during leather production. Chromium is an important health risk factor for the tannery workers which may enter the body by inhalation, ingestion and by direct cutaneous contact and cause several health problems of skin and respiratory tract. With the increase of unplanned industries, Bangladesh poses a new challenge to combat health hazards associated with heavy metal toxicity in soil.

Objective: The present study was designed to find out possible toxic effects of heavy metals in soil and health hazards among the people residing at tannery industries area.

Materials and Methods: This is a descriptive cross-sectional study and was carried out in two phases during the period of 1st November 2009 to 30 June 2010. In first phase the soil samples were taken from lagoons of Hazaribagh Thana of Dhaka city for laboratory test of heavy metals. In second phase, a total 190 respondents were interviewed using a semi-structured questionnaire to ascertain the common health problem around the tannery industries.

Results: All the eight soil samples contained $\mathrm{Cr}, \mathrm{Mn}, \mathrm{Ni}, \mathrm{Fe}, \mathrm{Pb}, \mathrm{Cu}$, where as $\mathrm{Cd}$ was nil. Mean distributor of $\mathrm{Cr}, \mathrm{Mn}, \mathrm{Ni}, \mathrm{Fe}, \mathrm{Pb}$ and $\mathrm{Cu}$ was 43.1325, 354.2217, 28.6633, 22420.1867, 97.5833 and $53.4633 \mathrm{ppm}$ respectively. $75.26 \%$ respondents stayed in the study area for six to ten years. Most of the respondents (75) were tannery workers. Total $52.85 \%$ households had toxicity related sickness in last six months. Among tannery workers most prevalent sickness were conjunctivitis (7.7\%) and Dermatitis (6.7\%). Regarding occurrence of clinical manifestations similar to Chromium toxicity in relation to staying in the study area, most of the households complained about allergy (39.2\%) and abdominal discomfort (24.4\%).

Conclusion: Elevated levels of urinary and blood Chromium is associated with high morbidity among the tannery workers. Therefore bio-monitoring of the heavy metals in the exposed workers is considered as a useful tool.
\end{abstract}

Key Words: Metal Toxicity, Health-Hazards, Tannery, lagoon, carcinogenic

\section{Introduction}

Leather production includes many operations with different exposures, which can be harmful and particularly be carcinogenic. ${ }^{1-3}$ Some compounds in the tanning process are considered as probably being carcinogenic to humans (some benzene-based dyes and formaldehyde). ${ }^{4-5}$ Besides these, scores of other

chemicals and organic solvents such as chromate and bichromate salts, aniline, butyl acetate, ethanol, benzene, toluene, sulfuric acid and ammonium hydrogen sulfide are used in the tannery industry. An important health risk factor for the tannery workers is occupational exposure to chromium,

${ }^{1}$ Lt Col Abu Noman Mohammed Mosleh Uddin, Associate Professor of Community Medicine, Armed Forces Medical College, Dhaka

${ }^{2}$ Prof. Sheikh Akhter Ahmed, Professor and Ex-Director of NIPSOM, Mohakhali, Dhaka

*Corresponding author

Date of submission: 14.10.17, Date of acceptance: 03.12.17

AKMMC J 2018; 9(1) : 39-43 
mainly in the organic $\mathrm{Cr}$ (III) form or in the protein bound-form (leather dust). Chromium may enter the body by inhalation, ingestion and by direct cutaneous contact. Professional exposure to $\mathrm{Cr}$ (III) increases the risk of dermatitis, ulcers and perforation of the nasal septum and respiratory illnesses as well as increased lung and nasal cancers. ${ }^{6-12}$ Cr-specific health hazards like carcinoma of the larynx and lung parenchyma and par nasal sinuses have also been reported. ${ }^{13-18}$ Bangladesh is a developing country with a population of about 152.5 million in a total area of $147570 \mathrm{sq} \mathrm{km}$, making it one of the most heavily populated countries of the world. Dhaka has been the capital city of Bangladesh since it achieved independence in 1971. The overall economy of Bangladesh has registered steady improvement with more than $6 \%$ average growth during the last five years. The industrial sector has been an important contributor to the country'sGDP19, its share standing at $28.6 \%$ in 2011.

The leather industry sector, which is the fourth largest foreign exchange earner of the country contributing about six per cent of total export earnings, produces 150 metric tons of solid waste every day contaminating the environment and water of the metropolis. With the increase of unplanned and socially and environmentally degraded industries Bangladesh poses a new challenge. Pollution and human-induced hazards are particularly serious in the Dhaka city. Tannery industries of Hazaribaghsituated in a heavily populated residential area. Out of 214 tanneries, 200 are located near the capital's river systems- the Turag to north-west, the Buriganga to the southwest and the Sitalakhya to the south-east, with Turag flowing into the Buriganga. Recently government of Bangladesh has shown much interest in environmental impact created by the industries, now they have planned to shift whole tannery to the Savar area for the safety of its citizen.

\section{Materials and Methods}

This is a descriptive cross-sectional study. The study was done in two phases during the period of $1^{\text {st }}$ November 2009 to 30 June 2010. In first phase, the soil samples were taken from up to $10 \mathrm{~cm}$ depth of total 3.58 square kilometer area of different places around the tannery industries in Hazaribagh Thana of Dhaka city. Four samples (numbered as 1 to 4) were collected within half kilometer of Lagoon and another four samples (numbered as 5 to 8 ) were collected after one kilometer of Lagoon. The collected materials were preserved into plastic containers for laboratory test of heavy metals like Chromium, Cadmium, Iron, Lead, Manganese, Nickel \& Copper level in the Institute of Bangladesh Council of Science \& Industrial Research (BCSIR).

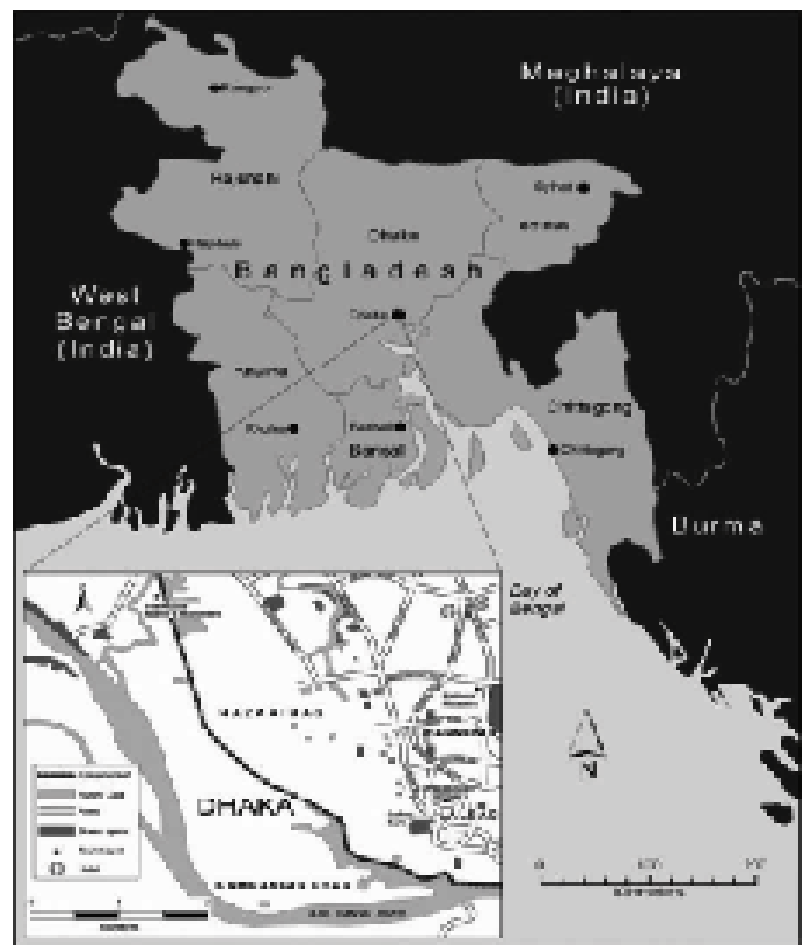

Fig-1: Bangladesh (inset-tannery locations)

In second phase, to ascertain the Common Health Problem around the Tannery Industries. A semistructured questionnaire were developed. The questions were pre-tested and finalized after necessary correction and relevant data were collected according to stratified cluster sampling procedure. A total 190 houses were randomly numbered and head of the households and his or her family members of respected houses were selected as respondents for the study. First 95 Houses were located in the first four sample size area that is stratum I and another 95 Houses were located in the 
Heavy Metal Contaminationof Soil and Health Hazards Among

second four sample size area that is stratum II. Then data were analyzed by using SPSS program.

\section{Results}

Table-I: Distribution of Heavy Metal Concentration in different soil Samples

\begin{tabular}{cccccccc}
\hline Id no & $\mathbf{C r}$ & $\mathbf{M n}$ & $\mathbf{N i}$ & $\mathbf{F e}$ & $\mathbf{P b}$ & $\mathbf{C u}$ & $\mathbf{C d}$ \\
\hline Sample1 & 91.62 & 760.41 & 39.25 & 34349.53 & 190.31 & 69.04 & 0 \\
Sample 2 & 76.08 & 682.88 & 37.27 & 34831.57 & 194.61 & 69.64 & 0 \\
Sample 3 & 121.27 & 676.67 & 40.39 & 33590.69 & 205.24 & 101.98 & 0 \\
Sample 4 & 86.41 & 659.92 & 41.84 & 32936.51 & 206.91 & 77.91 & 0 \\
Sample 5 & 5.13 & 158.35 & 31.27 & 7368.02 & 10.93 & 29.52 & 0 \\
Sample 6 & 1.95 & 178.05 & 28.14 & 7454.5 & 9.97 & 26.81 & 0 \\
Sample 7 & 8.46 & 172.05 & 33.88 & 7321.42 & 9.84 & 26.37 & 0 \\
Sample 8 & 2.73 & 191.77 & 30.93 & 7940.94 & 9.92 & 30.32 & 0 \\
\hline
\end{tabular}

Table-II: Distribution of mean Heavy Metal concentration in soil samples

\begin{tabular}{|c|c|c|c|c|c|c|}
\hline & $\begin{array}{c}\text { Chromium } \\
\text { ppm }\end{array}$ & $\begin{array}{c}\text { Manganese } \\
\text { ppm }\end{array}$ & $\begin{array}{c}\text { e Nickel } \\
\text { ppm }\end{array}$ & $\begin{array}{l}\text { Iron } \\
\text { ppm }\end{array}$ & $\begin{array}{l}\text { Lead } \\
\text { ppm }\end{array}$ & $\begin{array}{c}\text { Copper } \\
\text { ppm }\end{array}$ \\
\hline & 43.1325 & 354. & 28.6633 & 22420 & 97.5833 & 353.4633 \\
\hline Range & 119.32 & 602.06 & 26.85 & 27510.15 & 197.07 & 75.61 \\
\hline Minimum & 1.95 & 158.35 & 14.99 & 7321.42 & 9.84 & 26.37 \\
\hline Maximum & 121.27 & 760.41 & 41.84 & 34831.57 & 206.91 & 101.98 \\
\hline
\end{tabular}

Table-III: Distribution of length of staying of the respondents in the study area

\begin{tabular}{|c|c|c|c|c|}
\hline Length of Stay & & ST-I & ST-II & Total \\
\hline Up to 05 years & $\begin{array}{c}\text { Count } \\
\% \text { of Total }\end{array}$ & $\begin{array}{c}6 \\
3.15 \%\end{array}$ & $\begin{array}{c}10 \\
5.26 \%\end{array}$ & $\begin{array}{c}16 \\
8.42 \%\end{array}$ \\
\hline Six to ten Years & $\begin{array}{c}\text { Count } \\
\% \text { of Total }\end{array}$ & $\begin{array}{c}77 \\
40.52 \%\end{array}$ & $\begin{array}{c}66 \\
34.73 \%\end{array}$ & $\begin{array}{c}143 \\
75.26 \%\end{array}$ \\
\hline More than ten years & $\begin{array}{c}\text { Count } \\
\% \text { of Total }\end{array}$ & 12 & 19 & 31 \\
\hline
\end{tabular}

Table-IV: Distribution of respondents by Occupation

\begin{tabular}{ccccc}
\hline \multirow{2}{*}{ Tannery worker } & \multicolumn{4}{c}{ Stratum } \\
& & ST-I & ST-II & Total \\
\cline { 2 - 5 } Business man & & & & \\
& Count & 39 & 35 & 75 \\
Service man & $\%$ of Total & $13.7 \%$ & $12.3 \%$ & \\
& & 6 & 6 & 12 \\
Laborer & Count & $2.1 \%$ & $2.1 \%$ & \\
& \% of Total & 26 & 27 & 53 \\
& & $9.1 \%$ & $9.5 \%$ & 50 \\
& Count & 24 & 26 & 50 \\
& \% of Total & $8.4 \%$ & $9.5 \%$ & \\
\hline
\end{tabular}

Table-V: Distribution by clinical manifestations similar to Chromium toxicity of Tannery workers and other occupation

\begin{tabular}{|c|c|c|c|c|}
\hline & & St-I & St-II & Total \\
\hline \multirow[t]{3}{*}{ Yes } & Count & 162 & 273 & 435 \\
\hline & $\begin{array}{l}\% \text { Any sickness in } \\
\text { last } 6 \text { months }\end{array}$ & $37.24 \%$ & $62.75 \%$ & $100.0 \%$ \\
\hline & $\%$ of Total & $19.68 \%$ & $33.17 \%$ & $52.85 \%$ \\
\hline \multirow[t]{3}{*}{ No } & Count & 250 & 138 & 388 \\
\hline & $\begin{array}{l}\% \text { Any sickness in } \\
\text { last } 6 \text { months }\end{array}$ & $64.43 \%$ & $35.56 \%$ & $100.0 \%$ \\
\hline & $\%$ of Total & $30.37 \%$ & $16.76 \%$ & $47.13 \%$ \\
\hline
\end{tabular}

Table-VI: Distribution by clinical manifestations similar to Chromium toxicity of Tannery workers and other occupation

\begin{tabular}{lcccc}
\hline Name of illness & $\begin{array}{c}\text { Tannery } \\
\text { worker }\end{array}$ & Other & Total & Remarks \\
\hline Diarrhoea & $8(2.8 \%)$ & $29(10.2 \%)$ & 37 & $*$ \\
Dermatitis & $19(6.7 \%)$ & $36(12.6 \%)$ & 55 & $*$ \\
Conjunctivitis & $22(7.7 \%)$ & $37(13 \%)$ & 59 & \\
& & & & \\
Skin ulcer & $10(3.5 \%)$ & $27(9.5 \%)$ & 37 & $*$ \\
Abdominal & $16(5.6 \%)$ & $32(11.2 \%)$ & 48 & \\
discomfort & & & & \\
Lung disease & $2(0.7 \%)$ & $12(4.2 \%)$ & 14 & \\
Peptic ulcer & $3(1.1 \%)$ & $7(2.5 \%)$ & 10 & \\
Scabies & $10(3.5 \%)$ & $15(5.3 \%)$ & 25 & \\
Total & 90 & 195 & 285 & \\
\hline
\end{tabular}


Table-VII: Distribution of the households by occurrence of clinical manifestations similar to Chromium toxicity in relation to staying in the study area

\begin{tabular}{lcccc}
\hline \multicolumn{5}{c}{ Length of Stay } \\
& Up to 05 years & 06 to 10 Years & $>10$ years & Total \\
\hline Diarrhea & $33(2.7 \%)$ & $73(6.1 \%)$ & $28(2.3 \%)$ & $134(11.1 \%)$ \\
Fever & $28(2.3 \%)$ & $85(7.1 \%)$ & $30(2.5 \%)$ & $143(11.9 \%)$ \\
Lung diseases & $4(.3 \%)$ & $44(3.7 \%)$ & $39(3.2 \%)$ & $87(7.2 \%)^{*}$ \\
Jaundice & $4(.3 \%)$ & $11(.9 \%)$ & $8(.7 \%)$ & $23(1.9 \%)^{*}$ \\
Dent Diseases & $4(.3 \%)$ & $44(3.7 \%)$ & $39(3.2 \%)$ & $54(4.5 \%)^{*}$ \\
Allergy & $104(8.6 \%)$ & $245(20.4 \%)$ & $123(10.2 \%)$ & $472(39.2 \%)^{*}$ \\
Abdominal & $85(7.1 \%)$ & $97(8.1 \%)$ & $75(6.2 \%)$ & $293(24.4 \%)^{*}$ \\
Discomfort & & & & \\
Nasal Ulcer & 0 & $15(1.2 \%)$ & $39(3.2 \%)$ & $54(4.5 \%)^{*}$ \\
Dermatitis & $52(4.3 \%)$ & $144(12 \%)$ & $55(4.6 \%)$ & $251(20.9 \%)^{*}$ \\
Scabies & $28(2.3 \%)$ & $115(9.6 \%)$ & $29(2.9 \%)$ & $172(14.3 \%)^{*}$ \\
Edema of face & $1(.1 \%)$ & $8(.7 \%)$ & $26(2.2 \%)$ & $35(2.9 \%)^{*}$ \\
Skin Ulcer & $71(5.9 \%)$ & $95(7.9 \%)$ & $52(4.3 \%)$ & $218(18.1 \%)^{*}$ \\
Loss of smell & $12(1 \%)$ & $120(10 \%)$ & $73(6.1 \%)$ & $205(17 \%)^{*}$ \\
\hline
\end{tabular}

\section{Discussion}

The results obtained for this study to examine the status of metals in tannery industries effluents and their contamination in associated soil. Generally concentrations of heavy metals in environment occur due to continuous disposal of untreated industrial effluents generated during operational phase of industries. Among various industries, tannery industries is major producer of heavy metals like chromium, iron, manganese, copper, lead, cadmium and nickel etc. Hence, all the collected samples were analyzed for chromium (VI), iron, manganese, copper, lead, cadmium and nickel. Of the total analyzed samples, six metals were detected in each sample, except Cadmium which was not detected in all the studied samples of soils. The average values of chromium recorded in soil samples are 93.84 ppm and $30.99 \mathrm{ppm}$ respectively. Stratum I samples contain maximum concentration of Chromium followed by Stratum II. This may be due to the fact as the water flows downstream, the dilution effect increases, as a result chromium and other heavy metal concentration gradually decreases away from main ditch ie lagoon. The effluent from tannery industries before being discharged into the Burigangariver, collected into lagoon by the side of the river Buriganga flood protection barrage, from this ditch the water containing effluents slowly discharged into the river through sluice gate. So heavy near ditch are very high. Chromium was reported in tannery waste contaminated soil of Vellore district of Tamil Nadu, ranged from 154.5 to $568.0 \mu \mathrm{g} / \mathrm{l}$, respectively. ${ }^{20}$ The effluent released on land particularly at high concentration $(100 \%)$ increased chromium content in soil. Both trivalent and hexavalent chromium ions are toxic to plant life. To find out the relationship of length of stay of in the area with the occurrence of clinical manifestation which may be related to heavy metal mainly chromium toxicity, it has been found that the occurrence of abdominal discomfort, skin ulcer, scabies, dermatitis dental disease including erosion/discoloration diarrhea, loss of smell and allergy were significantly high among the people of stratum-I, which were gradually reduced in stratumII. People who were staying 6-10 years duration suffered more. The relationship of occurrence of disease with length of occupation of the workers have also been found in many studies. ${ }^{21,22}$

\section{Conclusion}

The high morbidity among the tannery workers may be due to elevated levels of urinary and blood chromium levels resulting from increased soil levels of chromium and other heavy metals at the work place. The study recommends that the biomonitoring of the heavy metals mainly chromium levels in the biological fluids can serve as a useful tool for mitigating the health hazards and risk factors in the exposed workers.

\section{Conflict of interest: None}

\section{References}

1. Stern FB. Mortality among chrome leather tannery workers: An update. Am J Ind Med 2003; 44: 197-206.

2. Issever $\mathrm{H}$, Ozdilli $\mathrm{K}$, Ozyildirim BA et al. Respiratory problems in tannery workers in Istanbul. Indoor Built Environ 2007; 16: 177-83.

3. Kornhauser C, Katarzyna W, Kazimierz Wet al. Possible adverse effect of chromium in occupational exposure of tannery workers. Industrial Health 2002; 40: 207-13. 
Heavy Metal Contaminationof Soil and Health Hazards Among

4. International Agency for Research on Cancer (IARC) IARC Monograph on the evaluation on the carcinogenicity risk of chemicals to human. Suppl 17. Vol.1-42. Lyon: IARC; 1987. Overall evaluation of carcinogenicity: An updating of IARC Monograph.

5. Budhwar R, Das M, Bihari V et al. Exposure estimates of chrome platters in India:an exploratory study. Biomarkers 2005; 10: 252-7.

6. Stern RM, Berlin A, Fletcher A. International conference on health hazards and biological effects of welding fumes and gases: Copenhagen 18-21, February, 1985. Int Arch Occup Environ Health 1986; 57: 237-46.

7. Angerer J, Amin W, Heinnrich-Ramm R. Occupational chronic exposure to metals. Arch Occupational Environ Health 1987; 59: 503-12.

8. Lin SC, Tai CC. Nasal septum lesion caused by chromium among chromium electroplating workers. Am J Ind Med 1994; 26: 221-8.

9. Stern AH, Bragt PC. Risk assessment of the allergic dermatitis: Potential of environmental exposure to hexavalent chromium. J Toxicol Environ Health 1993; 40: 613-41.

10. Mikoczy Z, Hagmar L. Cancer incidence in the Swedish leather tanning industry: Updated findings 1958-99. Occup Environ Med 2005; 62: 461-4.

11. Veyalkin LV, Milyutin AA. Proportionate cancer mortality among workers in the Belarussian tanning industry. Am J Ind Med 2003; 44: 637-42.

12. Basketter D, Horev L, Slodovnik D, Merimes $\mathrm{S}$, Trattner A, Ingber A. Investigation of the threshold for allergic reactivity to chromium. Contact Dermatitis 2001; 44: 70-4.
13. Walsh EN. Chromate hazards in industry. J Am Med Assoc 1953; 153: 1305-8.

14. Browning E. Toxicity of industrial metals. 2nd ed. London: Butterworth 1975: 119-31, 249-60.

15. Royale H. Toxicity of chromic acid in chromium plating industry. Environ Res 1975; 10: 39-53.

16. Langardt S. One hundred years of chromium and cancer: A review of epidemiological evidence and selected case reports. Am J Ind Med 1990; 17: 189-215.

17. Mikoczy Z, Hagmar L. Cancer incidence in the Swedish leather tanning industry: Updated findings. Occup Environ Med 2005; 62: 461-4, 1958-99.

18. Rastogi SK, Kesavchandran C, Mahdi F et al. Occupational cancers in leather tanning industries: A short review. Indian J Occup Environ Med 2007; 11: 3-5.

19. Bangladesh Country Report, Homepage of Global Finance 2010, Dhaka, Bangladesh.

20. Mahimairaja. An overview of heavy metals: impact and remediation. Current Science 2000; 78(7): April 10.

21. Norseth T. Cancer hazards caused by nickel and chromium exposure. J Toxicol, environ health 1980; 6: 1218-27.

22. Lanard S, Andersen A\&Gylseth B. Incidence of cancer among ferrochromium and ferrosilicon workers. Br J ind Med 1980; 37: 114-20. 